\title{
Cortisol as a Predictor of Early Mortality in Heart Failure
}

\author{
- Mehmet Yamak, 'ㅁ Hatice Tükenmez,, 2 (1) Meltem Sertbaş, ${ }^{3}$ \\ - Mehmet Akif Tükenmez, ${ }^{2}$ ㅇ Süleyman Ahbab, ${ }^{1}$ \\ - Hayriye Esra Ataoğlu
}

\begin{abstract}
'Department of Internal Medicine Health Sciences University, Hasek

Training and Research Hospital, Istanbul, Turkey

${ }^{2}$ Department of Internal Medicine, Niksar State Hospital, Tokat, Turkey ${ }^{3}$ Department of Internal Medicine Health Sciences University, Fatih Sultan Mehmet Training and Research Hospital, Istanbul, Turkey

Submitted: 31.07.2019 Accepted: 24.09.2019
\end{abstract}

Correspondence: Mehmet Yamak, Haseki Eğitim ve Araştırma Hastanesi, Sağlık Bilimleri Üniversitesi, İç Hastalıkları Anabilim Dalı, İstanbul, Turkey

E-mail:m-yamak@hotmail.com

Keywords: Cortisol level;
heart failure; prognosis.

\begin{abstract}
Objective: In several studies, chronic heart failure has shown to be associated with cortisol levels as increasing morbidity and mortality. The present study aims to evaluate the relationship between serum cortisol levels measured at hospitalization and 48 hours after the first sample with the early and late mortality rate at follow up period in patients with chronic heart failure.
\end{abstract}

Methods: Overall, 66 patients ( 36 female, 30 male) admitted with the diagnosis of heart failure were included in this study. First cortisol level measurement at the admission, and the second after 48 hours were made. Patients who died within the first sixty days were considered as early mortality and patients who died within 60-180 days as late mortality.

Results: After six months of follow up, overall, 18 out of 66 patients died. First, cortisol levels were established to be higher in the mortality group than the patients survived ( $18.84 \pm 5.39$ vs $15.47 \pm 4.95 ; p=0.028)$. The mortality rate was also found to be higher in the groups with NYHA class III-IV $(p=0.033)$, in male sex $(p=0.045)$, in the group with higher BMI $(p=0.036)$, while it was found to be lower in the patients with hypertension group. In cox regression analysis with a model of gender, BMI, NYHA stage, Hypertension and cortisol levels, it was established that high NYHA stage 2.6I4 [1.017-6.7I7] $(p=0.046)$, lack of HT $0.358[0.139-0.921](p=0.033)$ and high cortisol levels 5.09I [I.757-I4.774] $(p=0.003)$ were factors predicting mortality.

Conclusion: In conclusion, a high level of serum cortisol is an independent predictor of early cause mortality risk in patients with chronic heart failure. Class III-IV NYHA and lack of HT were found to be other established factors influencing mortality rate of these patients.

\section{INTRODUCTION}

Heart failure is considered a major public health problem wordwide with the inability of the heart to pump adequate blood to the periphery to meet the metabolic demands of the tissues. ${ }^{[1]}$ Heart failure comprises various heart diseases, such as (hypertension, coronary artery disease, heart valve diseases, myocarditis, and cardiomyopathy, impairing the function of the myocardium. ${ }^{[2,3]}$ In addition to the aging of the community and the development of treatment modalities, heart failure has become one of the most common chronic diseases with its increasing prevalence. ${ }^{[4]}$ The prevalence of heart failure accounts for approximately $2.2 \%$ over 20 years of age. ${ }^{[5]}$ With a prevalence of $14.4 \%$, heart failure the third most common disease-causing deaths due to chronic diseases in Turkey. ${ }^{[6]}$

Cortisol is a steroid hormone that regulates a wide range of vital processes throughout the body, including metabolism and the immune response, as well as helping the body to respond to stress. ${ }^{[7]}$ It has been shown that cortisol increase in the case of heart failure and stress (pyrogens, surgical intervention, hypoglycemia, exercise and severe emotional trauma) by the activation of hypothalamic-pituitary-adrenal axis, which stimulate the corticotropin release from the hypophysis gland. Hence, cortisol release from the adrenal cortex. ${ }^{[8]}$ In acute or chronic diseases, higher cortisol concentrations can be seen with higher adverse outcomes, including higher mortality rates. ${ }^{[9-14]}$ In some of these studies, morning serum cortisol and in others morning or evening salivary, cortisol were taken to show the relationship with mortality. ${ }^{[15]}$ The present study aims to evaluate the relation between serum cortisol levels measured at hospitalization and 48 hours after hospitalizations with a mortality rate at follow up in patients with chronic heart failure. 


\section{MATERIALS AND METHODS}

Patients with chronic heart failure who were admitted to an internal medicine clinic for any reason were enrolled in the present study. Overall, 66 (36 female, 30 male) patients were included in this study. The diagnosis of heart failure was made based upon physical examination, symptoms and echocardiographic examination. $\left.\right|^{\text {st }}$ and $2^{\text {nd }}$ cortisol levels were measured at the time of admission and 48 hours later, the first sample. Patients who were lost within the first sixty days were considered as early mortality, while patients who were lost within 60-180 days as of late mortality. In addition, a cut-off level of $22 \mu \mathrm{g} / \mathrm{dl}$ was determined higher than expected. Patients who had pathology in the adrenal axis and who used systemic corticosteroids for any reason, patients who had advanced liver and renal failure were excluded from this study. For classification of heart failure in the patients, NYHA and ACC/AHA classifications were used. ${ }^{[16-17]}$ Approval for this study was obtained from the local ethics committee.

All data obtained in the present study were recorded in the computer and were evaluated using SPSS for Windows I6.0 program. For descriptive statistics, continuous variables were expressed as mean and standard deviation and categorical variables with percentages. Data distribution was evaluated by Kolmogorov-Smirnov test for the evaluation of the relationship between certain variables and cortisol level and mortality; multivariate logistic regression analysis was carried out. In the comparisons between more than two groups, due to the distribution of data, either One-Way Anova or Kruskal Wallis test was used.

\section{RESULTS}

During the follow-up for 180 days, mortality was seen in 18 of the 66 patients. Median duration of hospitalization was five (I-25 days) days [no mortality five (I-I5); mortality seven $(I-25)],(p=0.14 I)$. First, cortisol levels were established to be higher in the mortality group than the patients survived during follow-up period (18.84 \pm 5.39 vs 15.47 $\pm 4.95 ; p=0.028$ ). Although the cortisol levels taken at the 48 hours were higher in the mortality group, it was not statistically significant ( $18.16 \pm 5.99$ vs $14.48 \pm 6.00$; $p=0.057)$. The mortality rate was also found to be higher in the groups with NYHA classification 3-4 $(p=0.033)$, in male sex $(p=0.045)$, in the group with higher BMI $(p=0.036)$, while it was found to be lower in the patients with hypertension group (Table I).

In Table 2, we compared the cortisol levels with three groups of patients as survived, early and late mortality. We saw that either $\left.\right|^{\text {st }}$ sample cortisol or $2^{\text {nd }}$ sample cortisol was obviously higher in the early mortality group rather than others $(p<0.05)$. When we took $22 \mathrm{mcg} / \mathrm{dl}$ as a cutoff value for cortisol, patients with higher cortisol levels at admission time had a significantly higher mortality rate than others $(p=0.00 \mathrm{II})$ (Table 3 ).

Patients with NHYA class III-IV, hypertension and cortisol were predictive of increased mortality risk in multivariable Cox regression: hazard ratio (HR) with $95 \%$ confidence interval of highest vs lowest tertile for hypertension: 0.358 [0.139-0.92I] $(p=0.033)$; for NHYA class III and IV: 2.614 [I.017-6.7I7] $(p=0.046)$ and for cortisol: 5.09I [1.75714.774] $(p=0.003)($ Table 4).

\section{DISCUSSION}

According to our findings, we confirmed that higher serum levels of cortisol are independent and complementary predictors of all-cause of early mortality in chronic heart failure patients. Higher Body Mass Index (BMI), male sex, higher NYHA stage with lack of hypertension were also found to be significantly different in the mortality group.

In their study, Yamaji et al. on outpatient clinic found that patients within the cardiac event group (cardiac death or hospitalization due to CHF) had higher cortisol levels than the group without cardiac event $(I 2.4 \pm 0.3 \mathrm{mcg} / \mathrm{dl}$ vs $16.8 \pm 1.8 \mathrm{mcg} / \mathrm{dl}) .{ }^{[14]}$

Güder et al. ${ }^{[13]}$ found that after the median follows up of the 803 days hazard ratio of cortisol was $2.72[95 \%$ confidence interval $[\mathrm{Cl}], 1.38$ to $5.36 ; p=0.004]$. They pre-

Table I. Effects of basal characteristics of patients on mortality

\begin{tabular}{|c|c|c|c|}
\hline & Survived $(n=48)$ & Mortality $(n=18)$ & $\mathbf{p}$ \\
\hline Age & $68.79 \pm 11.69$ & $71.63 \pm 10.25$ & 0.358 \\
\hline Gender (F/M) & $30 / 18$ & $6 / 12$ & 0.045 \\
\hline BMI & $26.11 \pm 5.10$ & $29.80 \pm 6.68$ & 0.036 \\
\hline HT (+), n-\% & $77-(37 / 48)$ & $44.4-(8 / 18)$ & 0.004 \\
\hline $\mathrm{DM}(+), \mathrm{n}-\%$ & $52-(25 / 48)$ & $44.4-(8 / 18)$ & 0.415 \\
\hline NHYA stage II/III-IV (n) & $33 / 15$ & $8 / 12$ & 0.033 \\
\hline LV \%EF & $48.22 \pm 11.99$ & $46.26 \pm 11.88$ & 0.551 \\
\hline Cortisol I ${ }^{\text {st }}(\mu g / d l)$ & $15.47 \pm 4.95$ & $18.84 \pm 5.39$ & 0.028 \\
\hline Cortisol $2^{\text {nd }}(\mu \mathrm{g} / \mathrm{dl})$ & $14.48 \pm 6.00$ & $18.16 \pm 5.99$ & 0.057 \\
\hline
\end{tabular}

BMI: Body mass index; HT: Hypertension; DM: Diabetes mellitus; NHYA: New York heart association classification; BP: Blood pressure; LV \%EF: Left ventricular $\%$ ejection fraction. 
Table 2. Evaluation of cortisol values and mortality

\begin{tabular}{lccc}
\hline Patients & n & Mean \pm SD & P \\
\hline $\begin{array}{l}\text { Cortisol It } \\
\quad \text { Survived }\end{array}$ & 48 & $15.47 \pm 4.95$ & \\
$\quad$ Early mortality & 10 & $24.62 \pm 13.89$ & 0.001 \\
$\begin{array}{l}\text { Sample }(\mu g / d) \\
\quad \text { Late mortality }\end{array}$ & 8 & $14.49 \pm 5.34$ & \\
$\quad$ Total & 66 & $16.88 \pm 7.89$ & \\
$\begin{array}{l}\text { Cortisol 2 } \\
\quad \text { Survived }\end{array}$ & 48 & $14.48 \pm 6.00$ & \\
$\quad$ Early mortality & 10 & $20.58 \pm 4.83$ & 0.036 \\
Sample $(\mu g / d)$ & & & \\
$\quad$ Late mortality & 8 & $14.93 \pm 6.23$ & \\
$\quad$ Total & 66 & $15.49 \pm 6.16$ & \\
\hline
\end{tabular}

Table 3. Relationship of cortisol levels and mortality

\begin{tabular}{lccc}
\hline & $\begin{array}{c}\text { Survived } \\
(\mathbf{n = 4 8 )}\end{array}$ & $\begin{array}{c}\text { Mortality } \\
(\mathbf{n}=18)\end{array}$ & P \\
\hline Cortisol $<22 \mu \mathrm{g} / \mathrm{dl}$ & 46 & $1 \mathrm{l}$ & $0.001 \mathrm{I}$ \\
Cortisol $>22 \mu \mathrm{g} / \mathrm{dl}$ & 2 & 7 & \\
Total & 48 & 18 & 66 \\
\hline
\end{tabular}

Table 4. Cox regression analysis with gender, BMI, NYHA stage, hypertension and cortisol levels

\begin{tabular}{lccc}
\hline & $95 \%$ Cl & HR & P \\
\hline Gender (male) & $0.735-5.188$ & 1.952 & 0.180 \\
BMI & $0.818-1.013$ & 0.910 & 0.084 \\
HT & $0.139-0.921$ & 0.358 & $\mathbf{0 . 0 3 3}$ \\
NHYA class III-IV & $1.017-6.717$ & 2.614 & $\mathbf{0 . 0 4 6}$ \\
Cortisol $(>22 \mu \mathrm{g} / \mathrm{dl})$ & $1.757-14.774$ & 5.091 & $\mathbf{0 . 0 0 3}$
\end{tabular}

BMI: Body mass index; HT: Hypertension; NHYA: New York heart association classification; $\mathrm{Cl}$ : Confidental interval; HR: Hazard ratio.

dicted cortisol as an independent risk factor for increased mortality. In another study, cortisol levels were found to be associated with mortality, just if the patients were not using mineralocorticoid receptor antagonists. ${ }^{\left[{ }^{11}\right]}$ Hammer et al. showed that evening salivary cortisol predicts increased mortality in heart failure rather than morning salivary cortisol. In compliance with other studies, especially the first sample, cortisol levels were found to be high in the mortality group. Different from the other studies, we also looked at the association of cortisol levels with early ( $1-60$ days) and late (60-180 days) mortality rates of the patients. We have found that cortisol levels were significantly higher in early mortality but not much predictive of mortality after the first sixty days. When cut-off value for high cortisol was taken as $22 \mathrm{mcg} / \mathrm{dl}$, mortality rates were significantly higher in the group, which was above the cutoff level (77\% vs 19\%).

When we made a model for cox regression analysis with gender, BMI, NYHA stage, hypertension and cortisol levels, it was established that the NYHA stage, lack of HT and cortisol levels were factors predicting survival. In the present study and the aforementioned studies, it was established that cortisol levels increased in chronic heart failure patients and that increased cortisol levels were associated with mortality and morbidity. In accordance with the literature and as expected, in our study, high NYHA classification was seen as an independent risk factor on mortality. ${ }^{[18]}$ Although conventional risk factors, such as hypertension, obesity and hyperlipidemia, have been indicated as an independently increased risk of developing CHF and mortality in the general population, there are also many reports that indicate increased serum cholesterol and higher blood pressure (BP) values strongly correlated with the decrease of mortality rate. [19,20] In Rotterdam study with 5255 participants, higher blood pressure and body mass index conferred more favorable in participants with heart failure. ${ }^{[2]}$ Cowie et al. ${ }^{[19]}$ showed that blood pressure was independently predictive of survival. Although it may seem inverse at first glance, our findings showed that the presence of hypertension in patients with heart failure has a decreasing effect on mortality in accordance with the studies published in the literature.

In conclusion, a high level of serum cortisol is an independent predictor of early cause mortality risk in patients with chronic heart failure. Class III-IV NYHA and lack of HT were also established to be the factors influencing the mortality. High cortisol levels predict early mortality and high levels of cortisone for the first 48 hours is one of the factors predicting mortality. In light of these findings, it is thought that close monitorization of these parameters, which can be readily followed in clinical practice, may help to the clinician for prediction of mortality easier.

Ethics Committee Approval

Haseki Training and Research Hospital Ethics Committee (date: 02.09.2015, no: 249).

Peer-review

Internally peer-reviewed.

Authorship Contributions

Concept: M.Y., H.T., S.A., M.A.T.; Design: H.T., M.A.T., M.Y.; Supervision: M.Y., S.A., H.E.A.; Data: M.Y., H.T., S.A., M.A.T.; Analysis: M.Y., M.S., H.T., M.A.T.; Literature search: M.Y., M.S., H.T.; Writing: M.Y., M.S., H.T., M.A.T., S.A.; Critical revision: M.Y., M.S.

Conflict of Interest

None declared. 


\section{REFERENCES}

1. Dickstein K, Cohen-Solal A, Filippatos G, McMurray JJ, Ponikowski P, Poole-Wilson PA, et al. ESC guidelines for the diagnosis and treatment of acute and chronic heart failure 2008: the Task Force for the diagnosis and treatment of acute and chronic heart failure 2008 of the European Society of Cardiology. Developed in collaboration with the Heart Failure Association of the ESC (HFA) and endorsed by the European Society of Intensive Care Medicine (ESICM). Eur J Heart Fail 2008;10:933-89. [CrossRef]

2. Marik PE, Zaloga GP. Adrenal insufficiency in the critically ill: a new look at an old problem. Chest 2002;122:1784-96. [CrossRef]

3. Fonseca C. Diagnosis of heart failure in primary care. Heart Fail Rev 2006;11:95-107. [CrossRef]

4. Lloyd-Jones D, Adams RJ, Brown TM, Carnethon M, Dai S, De Simone G, et al. Executive summary: heart disease and stroke statistics--2010 update: a report from the American Heart Association. Circulation 2010;121:948-54. [CrossRef]

5. Bui AL, Horwich TB, Fonarow GC. Epidemiology and risk profile of heart failure. Nat Rev Cardiol 2011;8:30-41. [CrossRef]

6. Unal B, Ergor G, Dinc G, et al. Chronic Diseases and Risk Factors Survey in Turkey. Ministery of Health Publication no:909 (2013) https://sbu.saglik.gov.tr/Ekutuphane/kitaplar/khrfai.pdf

7. van Cruijsen N, Dullaart RP, Wit HP, Albers FW. Analysis of cortisol and other stress-related hormones in patients with Ménière's disease. Otol Neurotol 2005;26:1214-9. [CrossRef]

8. Ho KK, Pinsky JL, Kannel WB, Levy D. The epidemiology of heart failure: the Framingham Study. J Am Coll Cardiol 1993;22:6A-13A.

9. Gracia-Iguacel C, González-Parra E, Egido J, Lindholm B, Mahillo I, et al. Cortisol levels are associated with mortality risk in hemodialysis patients. Clin Nephrol 2014;82:247-56. [CrossRef]

10. Marklund N, Peltonen M, Nilsson TK, Olsson T. Low and high circulating cortisol levels predict mortality and cognitive dysfunction early after stroke. J Intern Med 2004;256:15-21. [CrossRef]

11. Güder G, Hammer F, Deutschbein T, Brenner S, Berliner D, Deubner $\mathrm{N}$, et al. Prognostic value of aldosterone and cortisol in patients hospitalized for acutely decompensated chronic heart failure with and without mineralocorticoid receptor antagonism. J Card Fail 2015;21:208-16. [CrossRef]

12. Lechin F, van der Dijs B, Lechin A, Orozco B, Lechin M, Báez S, et al. Plasma neurotransmitters and cortisol in chronic illness: role of stress. J Med 1994;25:181-92.

13. Güder G, Bauersachs J, Frantz S, Weismann D, Allolio B, Ertl G, et al. Complementary and incremental mortality risk prediction by cortisol and aldosterone in chronic heart failure. Circulation 2007;115:175461. [CrossRef]

14. Yamaji M, Tsutamoto T, Kawahara C, Nishiyama K, Yamamoto T, Fujii M, et al. Serum cortisol as a useful predictor of cardiac events in patients with chronic heart failure: the impact of oxidative stress. Circ Heart Fail 2009;2:608-15. [CrossRef]

15. Hammer F, Deutschbein T, Marx A, Güder G, Michalski R, Ertl G, et al. High evening salivary cortisol is an independent predictor of increased mortality risk in patients with systolic heart failure. Int J Cardiol 2016;203:69-73. [CrossRef]

16. The Criteria Committee of the New York Heart Association. In: Dolgin $\mathrm{M}$, editor. Nomenclature and Criteria for Diagnosis of Diseases of the Heart and Great Vessels. 9th ed. Boston, Mass: Little, Brown \& Co; 1994. p. 253-6.

17. Villacastín J, Bover R, Castellano NP, Moreno J, Morales R, García-Espinosa A. Risk stratification and prevention of sudden death in patients with heart failure. Rev Esp Cardiol 2004;57:768-82. [CrossRef]

18. Ahmed A, Aronow WS, Fleg JL. Higher New York Heart Association classes and increased mortality and hospitalization in patients with heart failure and preserved left ventricular function. Am Heart J 2006;151:444-50. [CrossRef]

19. Cowie MR, Wood DA, Coats AJ, Thompson SG, Suresh V, Poole-Wilson PA, et al. Survival of patients with a new diagnosis of heart failure: a population based study. Heart 2000;83:505-10. [CrossRef]

20. Kalantar-Zadeh K, Block G, Horwich T, Fonarow GC. Reverse epidemiology of conventional cardiovascular risk factors in patients with chronic heart failure. J Am Coll Cardiol 2004;43:1439-44. [CrossRef]

21. Mosterd A, Cost B, Hoes AW, de Bruijne MC, Deckers JW, Hofman $\mathrm{A}$, et al. The prognosis of heart failure in the general population: the Rotterdam Study. Eur Heart J 2001;22:1318-27. [CrossRef]

\section{Kalp Yetersizliğinde Erken Mortalite Belirteci Olarak Kortizol}

Amaç: Çeşitli çalışmalarda, kronik kalp yetersizliğinde görülen morbidite ve mortalitenin artışının kortizol düzeyleri ile ilgili olduğu göserilmiştir. Bu çalışmada kronik kalp yetersizliği olan hastalarda hastanede yatış sırasında ve bundan $\mathbf{4 8}$ saat sonra alınan kortizol ölçümlerinin takip sürelerinde erken ve geç mortaliteyle ilişkisinin bakılması amaçlandı.

Gereç ve Yöntem: Çalışmaya kalp yetersizliği tanısı bulunan 66 hasta dahil edildi (36 kadın, 30 erkek). ilk kortizol ölçümü hasta yatış için başvurduğunda, ikinci kortizol ölçümü ilk ölçümden 48 saat sonra yapılmışır. Illk altmış gün içinde ölen hastalar erken mortalite ve 60 - 180 gün içinde ölenler geç mortalite olarak kabul edildiler.

Bulgular: Altı aylık takip sonrasında 66 hastanın I8'i hayatını kaybetti. Illk kortizol ölçümleri mortalite grubunda sağ kalan hastalara göre yüksek bulundu (I8.84 \pm 5.39 ve $15.47 \pm 4.95 ; p=0.028)$. ölüm oranı NYHA sınıf III-IV ( $p=0.033)$, erkek cinsiyet $(p=0.045)$, vücut kitle indeksi yüksek (VKI) ( $p=0.036)$, olan gruplarda yüksek iken hipertansiyonu bulunan hasta grubunda daha düşük bulundu. Cinsiyet, VKI, NYHA sınıfı, hipertansiyon ve Cox regresyon analizinde, yüksek NYHA sınıf 2.614 [I.017-6.717] ( $p=0.046)$, hipertansiyonun olmaması 0.358 [0.1390.921 ] $(p=0.033)$ ve kortizol düzeyleri 5.09। [ I.757-14.774] $(p=0.003)$ mortaliteyi öngören faktörler olarak bulundu.

Sonuç: Sonuç olarak, yüksek serum kortizol düzeyleri kronik kalp yetersizliği olan hastalarda erken ölüm riskinin bağımsız bir belirleyicisidir. Sınıf III-IV NYHA olması yanında hipertansiyon varlığının bulunmamasıda diğer belirlenmiş risk faktörleri olarak gösterilmiştir.

Anahtar Sözcükler: Kortizol seviyesi; kalp yetersizliği; prognoz. 